\title{
Islam and Good Governance: An Annotated Bibliography
}

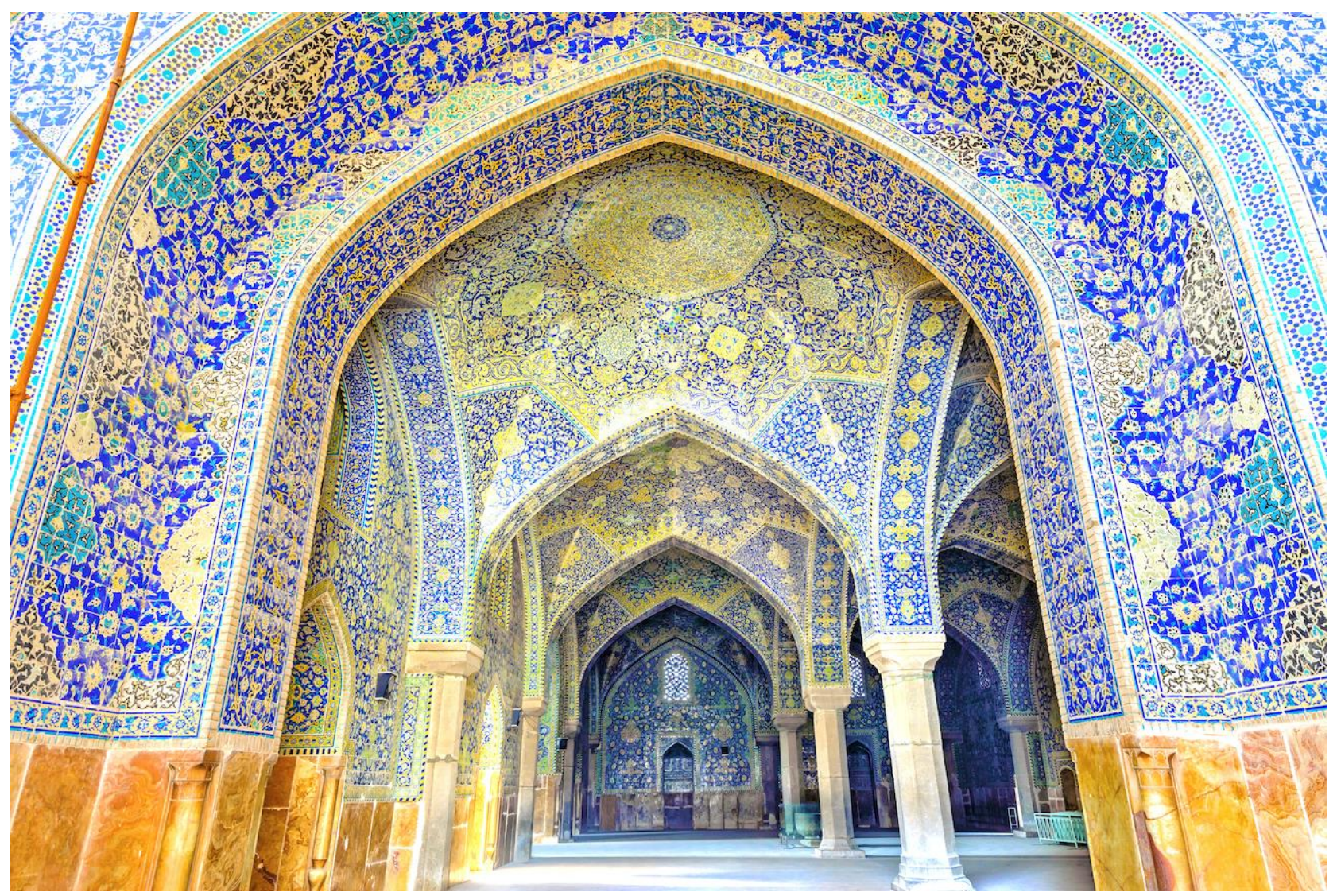

\section{Mohammed Ayub Khan}

\author{
Doctoral Candidate
}

McMaster University, Hamilton, Canada

Symposium on Islam and Good Governance

Muqtedar Khan (Ed.)

International Institute of Islamic Thought | October 2020

DOI: 47816/01.007.20 
Abdelgafar, Basma. Public Policy: Beyond Traditional Jurisprudence. London: International Institute of Islamic Thought, 2018.

This work is an attempt to deploy the maqasid (higher objectives of Shariah) approach to public policy. It argues that public policy in Islam is a qualitatively distinct enterprise and should not be looked at only from the fiqh perspective. It is the author's contention that the maqasid approach can resolve many of the governance dilemmas which have been dogging the Muslim world throughout its history.

Afsaruddin, Asma (ed.). Islam, the State, and Political Authority: Medieval Issues and Modern Concerns. New York: Palgrave Macmillan, 2011.

The diverse set of essays in this book address the "temporality" of Islamic notions of governance and cover both the pre-modern and modern periods. This book offers a comprehensive review of notions of governance from Sunni, Shia, Mutazila, and other sources. The chapters present new insights into the assumed relationship between theology and ideas on political authority in the writings of Muslim scholars.

Al-Ahsan, Abdullah, and Stephen Young (eds.). Qur'anic Guidance for Good Governance: A Contemporary Perspective. New York: Springer International, 2018.

This collection explores the principles of good governance deduced from the Holy Qur'an and their relevance to organizing of contemporary societies.

Alam, Muzaffar. The Languages of Political Islam in India: 1200-180o. New Delhi: Permanent Black, 2004.

This book offers an analysis of political texts from Muslim-ruled India. The texts under study are of the akhlaq and $a d a b$ genre which are generally classified under 
the "mirror of princes" literature. The author argues that there is a qualitative difference between them. The texts analyzed include Barani's Fatawa-eJahandari, Fakhr-i Mudabbir's Adab al Harb, and Hamadani's Zakhirat ul Muluk. In addition, the author also provides an overview of North Indian Sufis' visions of power. The author shows the creative tension within Indian Islamic polities and demonstrates that they had much that was original about them.

Alvi, Sajida S. (ed.). Advice on the Art of Governance: An Indo-Islamic Mirror for Princes (Translation of Muhammad Baqir Najm-i-Sani’s Maui'zah-I Jhangiri) Albany: State University of New York Press, 1989.

This work is a translation of a work on governance by a high-ranking Mughal noble of early seventeenth century. It provides a good introduction to the Mughal way of thinking on statecraft, justice, discipline, consultation as well as planning, and foreign policy. The translator's introduction provides a detailed thematic analysis of the Indo-Islamic Mirrors of Princes from thirteenth to seventeenth centuries.

Ardic, Nurullah. Islam and the Politics of Secularism: The Caliphate and Middle East. London: Routledge, 2017.

This book provides a historical description of the process of secularization in the Middle East in the nineteenth century. The author argues that the relationship between Islam and secularism was one of accommodation. He offers an in-depth analysis of Turkish modernists who deployed Islamic arguments in their quest to modernization of governing institutions.

Asad, Muhammad. Principles of State and Government in Islam. Berkeley: University of California Press, 1961. 
This book by the late scholar Muhammad Asad provides a contemporary approach to the relevance of Shariah to modern state building and statecraft. He contends that Shariah "is far more concise and very much smaller in volume than legal structure evolved through fiqh of various schools of Islamic thought." (p.12) He highlights the importance of ijtihad which allows for flexibility in the building of state institutions. He demonstrates that Shariah "does not prescribe any definite pattern to which an Islamic state must conform, nor does it elaborate in detail a constitutional theory." (p.22) He emphasizes the importance of consent and counsel in arriving at governing decisions.

Baali, Fuad. Society, State, and Urbanism: Ibn Khaldun's Sociological Thought. Albany: State University of New York Press, 1988.

This book offers a thorough analysis of ibn Khaldun's thought and convincingly demonstrates that he indeed laid the foundations of what came to be known as sociology (ilm ul umran in ibn Khaldun's words). Chapters 4, 5, and 6 are important from a governance perspective where Ibn Khalduns's thought on qualities of leadership, factors for the decline of the state, and the cyclical pattern of history are discussed in ample detail. Chapter 7 is an examination of urbanization and local governance (town planning, etc.) as expounded by ibn Khaldun.

Bennett, Clinton and Sarwar Alam (eds.). Sufism, Pluralism and Democracy. Bristol, CT: Equinox Publishing Ltd, 2017.

This volume brings together a range of scholarship on the involvement of Sufis in contemporary politics. The authors show that the prevailing notions of Sufis as apolitical are incorrect. This book makes an original contribution on the Sufi conceptions of power, state, democracy, and governance. 
Boroujerdi, Mehrzad (ed.). Mirror for the Muslim Prince: Islam and the Theory of Statecraft. Syracuse, NY: Syracuse University Press, 2017.

This collection of essays is an attempt to reinterpret and reassess the concepts of politics and governance in Islamic thought from Arab, Persian, South Asian, and Turkish traditions. The contributors demonstrate that there has been a great deal of diversity in Muslim thought over issues like the building blocks of an Islamic state, the meaning of public interest, and theory of government.

Diouf, Mamadou Seck (ed.). Tolerance, Democracy, and Sufis in Senegal. New York: Columbia University Press, 2013.

This collection of essays emerged out of a conference at Columbia University in 2008. They offer original insights on Sufi engagement with political power in particular locales. There is thorough discussion on the Senegalese social contract, dubbed the "Islamo-Wolof model," which is based on Sufi leaders mediating between their followers and the state.

Hashemi, Nader. Islam, Secularism, and Liberal Democracy: Toward a Democratic Theory for Muslim Societies. Oxford: Oxford University Press, 2014.

This book challenges the assumption that Islam and liberal-democratic development are incompatible. It argues that an organic theory of Muslim secularism is possible and necessary for the development of liberal democracy in Muslim societies. The book offers a fresh democratic theory for Muslim societies.

Imamuddin, S. M. Arab Muslim Administration. Delhi: Kitab Bhavan, 1984. 
This is an empirical study of administrative systems in Arab territories from 622$1258 \mathrm{CE}$. It provides a general overview of theories of administration and institutional change during the era.

Iqbal, Zafar, and Mervyn Lewis. An Islamic Perspective on Governance. Cheltenham, UK: Edward Elgar, 2009.

The authors of this book apply the Islamic lens to important issues in public, economic, and corporate governance. They analyze theories of justice, taxation, budget deficits, accountability, and corruption. They bring together Islamic scholarly views on public welfare through the classification of spheres of liberties and violation. The authors bring to light the views of an eclectic mix of historical and contemporary Islamic scholars including al-Ghazali, ibn Rushd, al-Shatibi, Maududi, and the Pakistani theologian Tahir ul Qadri.

Khan, Muqtedar. Islam and Good Governance: A Political Philosophy of Ihsan. New York: Palgrave Macmillan, 2019.

This book is a sophisticated analysis of good governance from the Islamic perspective. The author, using his expertise in both political science \& Islamic studies, develops an Islamic political philosophy of governance grounded on Ihsan. Ihsan is defined as spiritual state which 'privileges process over structure, deeds over identity, love over law and mercy and forgiveness over retribution.' The book calls for a rethinking of Islamic priorities and marks a shift from the structure oriented contemporary Islamist politics.

Kuru, Ahmet T. Islam, Authoritarianism, and Underdevelopment. Cambridge:

Cambridge University Press, 2019.

This book is an attempt to understand the reasons behind authoritarianism and underdevelopment in Muslim countries. Moving away from essentialist arguments, the author traces a longer arc of decline marked by an alliance of conservative 
religious scholars and state officials. The author also demonstrates that the many of the models of governance in Muslim countries are based on national \& cultural traditions and not on Qur'anic values.

Lambton, Ann K.S. State and Government in Medieval Islam. New York: Oxford University Press, 1981.

This volume is a study on the Muslim idea(s) of state as expounded by jurists from eighth to seventeenth centuries. It is limited to the central lands of the Caliphate, including Iran and North Africa. Some non-jurists, however, have been included because of their importance (like ibn Al Muqaffa and al-Jahiz).

Lakhani, M. Ali., Reza Shah-Kazemi, and Leonard Lewisohn. The Sacred Foundations of Justice in Islam: The Teachings of 'AlíIbn Abi'Tatib. Bloomington: World Wisdom, 2006.

This book is a reflection on the teachings of Ali ibn Abi Talib on a variety of subjects, including governance. The authors argue that Ali ibn Abi Talib's teachings called for "principled pluralism" in the realm of governance. It offers an enriching theoretical discussion related to governance.

Lo, Mbaye. Political Islam, Justice and Governance. New York: Palgrave Macmillan, 2019.

This book is a study of contemporary Islamist movements and their conceptions of governance. He argues that modern Islamic parties failed to govern effectively because they were not able to reconcile between individual freedoms and the literal ideas of justice. The book offers case studies from Egypt, Sudan, and Syria. 
Malik, Maszlee. Foundations of Islamic Governance: A Southeast Asian Perspective. London: Routledge, 2018.

The author of this book introduces a prescriptive element to the issue of governance and Islam. He argues that Islam has much to offer to the contemporary world through the "micro-method" of producing "the homoislamicus" or the ideal Islamic person. He offers an expansive definition of good governance not limited to materialist components but encompassing a value-laden conception of humanity. He calls this "ihsani social capital."

Mohamad, Maznah. The Divine Bureaucracy and Disenchantment of Social Life: A Study of Bureaucratic Islam in Malaysia. Singapore: Palgrave Macmillan, 2020.

This book is an empirical study of bureaucratic Islam in Malaysia. The author argues that the real agent of Islamization in the country is the bureaucracy which is advantageously situated and has divinity as well as sacrality attached to it.

Najem, Tom, and Martin Hetherington (eds.). Good Governance in the Middle East Oil Monarchies. London: Routledge Curzon, 2003.

This book studies the concept of good governance and how it is applied in the states of Gulf Cooperation Council. It argues that Western notions of good governance need to be modified in order to be effectively implemented in this region.

Riaz, Ali and C. Christine Fair (eds.). Political Islam and Governance in Bangladesh. London: Routledge, 2015.

This edited volume brings academics and journalists to examine the impact of Islamist politics on governance in Bangladesh. The authors argue that Islamist politics will continue to have mass appeal in the country and charts how it has been impacting public policy over the years. 
Rabi', Muhammad Mahmoud. The Political Theory of Ibn Khaldun. Leiden: E.J. Brill, 1967.

This book is an attempt to understand ibn Khaldun's political theory and its influences. Concepts like benevolence, force, etc., are discussed in adequate detail.

Rauf, Feisal Abdul. Defining Islamic Statehood: Measuring and Indexing Contemporary Muslim States. New York: Palgrave Macmillan, 2015.

This book provides an analysis of the modern Islamic state applying a quantitative measurement of how Muslim majority nations meet the definition. It is a result of the author's engagement with a panel of Sunni and Shia scholars over seven years. The author deploys an innovative maqasid approach to score the Muslim countries on good governance.

Saeed, Abdullah (ed.). Islamic Political Thought and Governance. London: Routledge, 2011.

This three-volume collection of essays is concerned with the development of Islamic political thought and governance broadly defined. They cover an extensive period from pre-Islamic Arabia to contemporary times. Shia, Sunni, Khariji, Mutazili, and other groups' views are thoroughly analyzed. The importance of this work is further enhanced by the deployment of the gender lens on governance in the chapters by Michaelle Browers and Ziba Mir-Hosseini.

Santini, Ruth, Abel Polese and Rob Kevlihan (eds.). Limited Statehood and Informal Governance in the Middle East and Africa. London: Routledge, 2020. 
This collection of essays is a study of hybrid forms of governance where the central state authority does not possess an exclusive monopoly of violence in Middle East and Africa. It redefines governance as inclusive of non-state actors.

Sherwani, Haroon Khan. Mahmud Gawan's Political Thought and Administration. Hyderabad, Deccan: Hyderabad Printing Works, 1937.

This book is a study of the fifteenth century Islamic scholar and Prime Minister Mahmud Gawan of the Bahmani kingdom of South India. Gawan is credited with improving bureaucratic and administrative practices in the region. This book is a close study of Gawan's Kitab ul Insha and charts out his influences in the quest for reform in a diverse polity.

Sherwani, Haroon. Muslim Political Thought and Administration. New Delhi: Mushiram Manoharlal Pub., 1981.

This neglected work, first published in 1941, provides a comprehensive view on Muslim political thought and administration. Sherwani provides an illustrative introduction by comparing Islamic thought with those of Confucius, Mencius, and Kautilya. He discusses the principles of order, peace and obedience, justice, social reform, toleration, and internationalism. He then provides a thorough overview of various Muslim scholars on governance and administration from ninth to fifteenth centuries. The scholars discussed include ibn Abir Rabi, al-Farabi, al-Mawardi, Amir Kaikaus, al-Ghazali, and Mahmud Gawan. This book presents in an accessible form the ideas of ibn Abir Rabi whose Suluk ul Mamalik fi Tadbiril Mamalik is “'the earliest philosophical treatise' by a Muslim in which are couched the principles of politics and administration." (p.69) This book can be considered the first complete attempt on the topic in the English language.

Springborg, Robert (ed.). Development Models in Muslim Contexts: Chinese, "Islamic" and Neo-Liberal Alternatives. Edinburgh: Edinburgh University Press, 2009. 
This volume of collected essays offers a comparative analysis of competing models of development in the Muslim world. Special attention is paid to the Chinese model and how it can be recalibrated in Muslim majority countries. The authors point to the centrality of governance to development.

Stephens, Julia Anne. Governing Islam: Law, Empire, and Secularism in South Asia. Cambridge: Cambridge University Press, 2018.

This book is a study of the colonial roots of Islamic law as it is practiced in India, Pakistan, and Bangladesh. It provides a nuanced discussion on the struggle between Islam and secularism in everyday lives and how colonial laws fostered their entanglement. The book uses a diverse set of sources, including Islamic fatwas and court documents.

Tamadonfar, Mehran. Islamic Law and Governance in Contemporary Iran: Transcending Islam for Social, Economic, and Political Order. Lanham: Lexington Books, 2017.

Tamadonfar attempts to offer answers to questions about the nature of the Islamic state from the Shia tradition. He focuses on the four-decade-long experience of the Islamic Republic of Iran in the realm of governance. He argues that this model is in need of modification to be applicable to modern societies and that Islam provides doctrinal and practical instruments for transcending the restrictions of Shariah. He suggests that pragmatism is necessary for orderly management of societies.

Tripathi, Ram P. Some Aspects of Muslim Administration. Allahabad: Central Book Depot, 1992.

This book was first published in 1936 and emerged out of the author's doctoral dissertation at the University of London. This is a comprehensive treatment of the 
varying conceptions of sovereignty in the Muslim dynasties of India. The author provides original analysis of the relationship between the sultans of Delhi and the Caliphate. The author identifies the question of succession as a major weakness of these dynasties. The second part of the book is devoted to the office of the wazir along with the Muslim theories of taxation and administration as they were implemented in India.

Wahba, Wafa (tr.). Al Mawardi’s The Ordinances of Government. Reading: Garnet, 2010.

This is a translation of the tenth century jurist al-Mawardi's seminal work $A l$ Ahkam Al Sultaniyya Wa'sal Wailayat al Diniyya. This work is considered to be the most profound statement on Islamic political theory.

Walzer, Richard (tr.). Al-Farabi on the Perfect State: Abu Nasr Al-Farabi's Mabadi Ara Ahl Al-Madina Alfadila. Oxford: Clarendon Press, 1985.

This book is a translation of al-Farabi's famous work, The Virtuous City. The translation is accessible and gives the reader a general understanding of al-Farabi's views on governance including the desirable qualities of rulers. The translation is useful despite some unsubstantiated claims of the translator like the enormity of Greek influence on al-Farabi. 


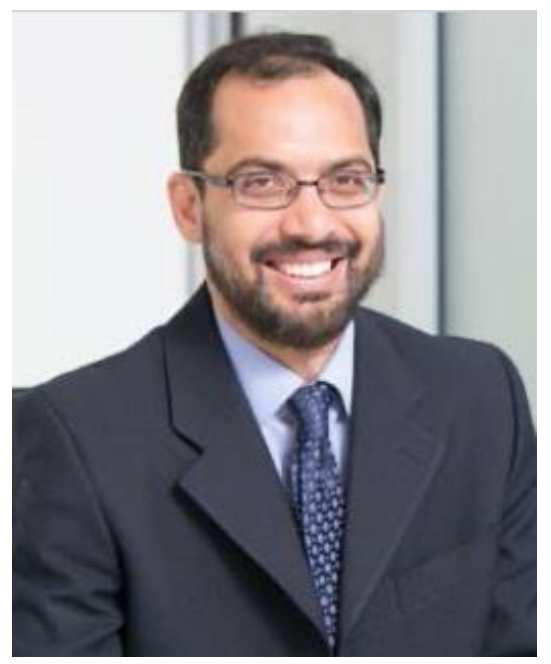

Mohammed Ayub Khan is a Toronto based researcher and public administration professional. He has worked at provincial and municipal levels of government and has vast experience of community engagement. He holds a BA in Political Science from York University (Toronto), MA from McMaster University (Hamilton), and is currently finishing his Phd.in Political Science. His academic research is focused on Muslim minority communities. His special areas of interest are waqf administration, affirmative action, social cohesion, and constitutional provisions for religious minorities. He has published academic articles in Journal of Muslims Minority Affairs, Muslim World Book Review, Journal of Fraser Valley University, Sikh Studies, etc. His chapter on Global Muslim Demography was published this year in Halal Food Production. He is currently undertaking a project on studying the social infrastructure of Muslim communities in the Greater Toronto Area. Mohammed Ayub Khan is involved with many community organizations and had served as the president of the American Federation of Muslims of Indian Origin. 